\title{
The ins and outs of sporozoite biology in the dermis
}

\author{
Christine Hopp, Photini Sinnis* \\ From Challanges in malaria research: Core science and innovation \\ Oxford, UK. 22-24 September 2014
}

Plasmodium sporozoites are inoculated by infected mosquitoes into the dermis of the mammalian host. Once in the skin, sporozoites use gliding motility to move within the dermis and find a blood vessel. They then breach the endothelial barrier, enter the bloodstream and go to the liver. Several mutants that we have generated as well as recent antibody-inhibition studies suggest that the skin is a bottleneck for the parasite and possibly one of our best opportunities to intervene. Using the rodent malaria model, we have begun to analyze sporozoite movement in the skin and the innate immune response to sporozoites delivered by mosquito bite. These data and their relevance to the malaria vaccine effort will be discussed.

Submit your next manuscript to BioMed Central and take full advantage of:

- Convenient online submission

- Thorough peer review

- No space constraints or color figure charges

- Immediate publication on acceptance

- Inclusion in PubMed, CAS, Scopus and Google Scholar

- Research which is freely available for redistribution

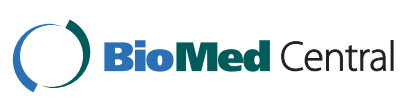

(C) 2014 Hopp and Sinnis; licensee BioMed Central Ltd. This is an Open Access article distributed under the terms of the Creative Commons Attribution License (http://creativecommons.org/licenses/by/4.0), which permits unrestricted use, distribution, and reproduction in any medium, provided the original work is properly cited. The Creative Commons Public Domain Dedication waiver (http://creativecommons.org/publicdomain/zero/1.0/) applies to the data made available in this article, unless otherwise stated. 